
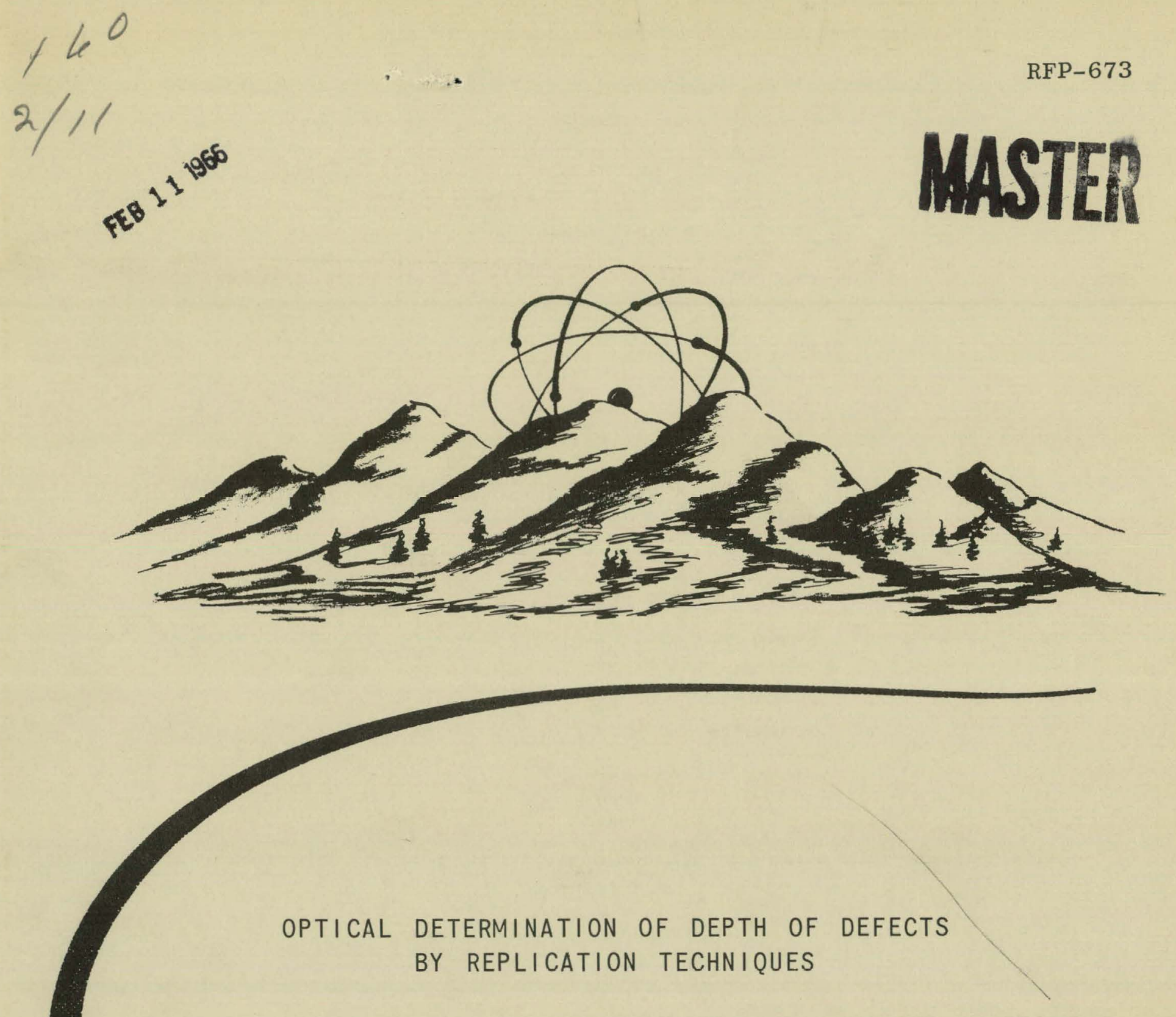

by

\begin{abstract}
D. V. Miley
V. K. Grotzlcy
\end{abstract}

160

\section{RELEASED FOR ANINOUTCEMIENT}

IN MUCTEAR SCIENCE ABSTRACTS

THE DOW CHEMICAL COMPANY

ROCKY FLATS DIVISION

P. O. BOX 888

GOLDEN, COLORADO 80402

U. S. ATOMIC ENERGY COMMISSION

CONTRACT AT(29-1)-1106 


\section{DISCLAIMER}

This report was prepared as an account of work sponsored by an agency of the United States Government. Neither the United States Government nor any agency Thereof, nor any of their employees, makes any warranty, express or implied, or assumes any legal liability or responsibility for the accuracy, completeness, or usefulness of any information, apparatus, product, or process disclosed, or represents that its use would not infringe privately owned rights. Reference herein to any specific commercial product, process, or service by trade name, trademark, manufacturer, or otherwise does not necessarily constitute or imply its endorsement, recommendation, or favoring by the United States Government or any agency thereof. The views and opinions of authors expressed herein do not necessarily state or reflect those of the United States Government or any agency thereof. 


\section{DISCLAIMER}

Portions of this document may be illegible in electronic image products. Images are produced from the best available original document. 


\section{LEG A L NOTICE}

This report was prepared as an account of Government sponsored work. Neither the United States, nor the Commission, nor any person acting on behalf of the Commission:

A. Makes any warranty or representation, expressed or implied, with respect to the accuracy, completeness, or usefulness of the information contained in this report, or that the use of any information, apparatus, method, or process disclosed in this report may not infringe privately owned rights; or

B. Assumes any liabilities with respect to the use of, or for damages resulting from the use of any information, apparatus, method, or process disclosed in this report.

As used in the above, "person acting on behalf of the Commission" includes any employee or contractor of the Commission, or employee of such contractor, to the extent that such employee or contractor of the Commission, or employee of such contractor prepares, disseminates, or provides access to, any information pursuant to his employment or contract with the Commission, or his employment with such contractor.

Printed in USA. Price $\$ 1$. Available from the Clearinghouse for Federal Scientific and Technical Information, National Bureau of Standards,

U. S. Department of Commerce, Springfield, Virginia 


\title{
OPTICAL DETERMINATION OF DEPTH OF DEFECTS BY REPLICATION TECHNIQUES
}

\author{
by \\ D. V. Miley \\ V. K. Grotzky
}

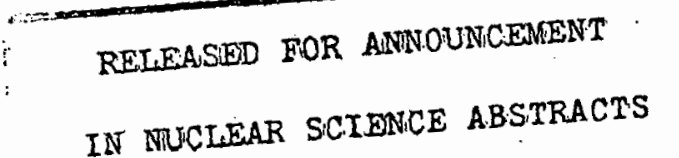

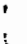

THE DOW CHEMICAL COMPANY

ROCKY FLATS DIVISION

P. O. BOX 888

COLDEN, COLÓRAADO 80402

U. S. ATOMIC ENERGY COMMISSION

CONTRACT AT $(29-1)-1106$ 


\begin{abstract}
Replication of defects was accomplished by a variety of techniques and produced accurate depth determinations. Of the replicating materials tested, General Electric RTV20 was most suitable for this application.

A microscope is required for depth determinations on replicated surface defects. Basically, this should be a binocular unit employing vertical illumination, with a fine focus mechanism graduated in microns. Examination is best accomplished at magnifications of 150-200X.
\end{abstract}




\section{INTRODUCTION}

Visual estimation has been the accepted method of determining the depth of surface defects on finished parts. A more desirable technique would provide measurements to an accuracy of \pm 0.001 in. with reproducibility of \pm 0.0005 in. and would be accomplished within 10 minutes. A study of replication methods was therefore undertaken to see if they would fulfill these requirements:

Replication is a technique widely used in electron microscopy and, to a lesser degree, in optical microscopy.' Basically, it is the formation of a cast of the sample surface; the cast, or replica, is subsequently examined at high magnification.

Of the materials most commonly used for replication, only plastics and RTV rubbers were considered for this investigation. 
RFP-673 


\section{TEST PROCEDURE}

A small sample of tantalum sheet stock with six scribed lines was employed for the investigation. The test lines were scribed to depths varying between 0.0038 and 0.0055 in., and two lightly scribed lines perpendicular to the test lines defined a length of 0.1 in. where all measurements were to be taken. The test lines were numbered 1 through 6 for identification.

A11 depth determinations were made on a Zeiss U1traphot II metallograph. This instrument is equipped with a graduated fine focus knob, and measurements were read to the nearest micron. The depth determination was made by focusing at the top of the defect and noting the fine focus position, and then focusing at the bottom of the defect and again recording the fine focus position. The difference in fine focus readings was the depth of the defect in microns.

In addition to the work on the scribed-line sample, replicas were made on a scrapped part to determine problems of replication in a glovebox.

\section{RESULTS AND DISCUSSION}

The accompanying table presents a summary of the depth measurements. Readings were made at $160 \mathrm{X}$ magnification, which was a convenient value with adequate resolution. In general, measurements on replicas were within the desired limits.

Five replicating materials were tested, and all but one were judged unsuitable for this application.

Polyvinyl alcohol (PVA) and Ladd replicating solution (1) both required an excessively long curing time. PVA was also difficult to strip after curing.

(1) Ladd Research Industries, Inc., Builington, Vcrmont 
One-, two-, and five-mil cellulose acetate (Fax*) replicas were made. Only the five-mil Fax film produced useable replicas. Replica quality was not sufficient, however, and subsequent depth measurements did not quite have the desired accuracy and precision. A coating of silver was vapor deposited onto several Fax replicas in an attempt to improve visibility. The silver coating did not result in any improvement.

Silastic (2) RTV521 silicone rubber is a room temperature vulcanizing rubber which requires the addition of a small amount of catalyst for curing. This material exhibited excellent penetration into the defects and produced high quality replicas resulting in accurate depth determinations. Unfortunately, RTV521 required several hours for curing and was therefore unsuitable for use.

General Electric RTV20 ${ }^{(3)}$ is similar to Dow Corning RTV521; however, only a few minutes curing time are required. RTV20 also produced excellent replicas with the desired accuracy and precision of depth determinations. A low viscosity mixture that cured in five to six minutes was made by adding 0.5 percent catalyst to the rubber." The addition of 5 percent catalyst reduced the curing time to one to two minutes.

From these observations, the General Electrie RTV20 was judged the best repilicating material of those tested for this application. Cellulose acetate could be used, but with slightly poorer reproducibility. RTV20 was also most convenient for glovebox use; specific suggestions are given on next page.

* Cellulose acetate film.

(2) Dow Corning, Midland, Michigan

(3) General Electric Company, Silicone Prod. Dept., Waterford, New York. 


\section{RECOMMENDATIONS}

These suggestions are based on the use of General Electric RTV20 for depth determination by replication. The use of any similar silastic would require only slight modifications.

1. Mix approximately 0.5 percent catalyst with the rubber. This produces a mixture thin enough to penetrate small surface defects and will allow one to two minutes of working time before curing advances. An amount of silastic about the size of a silver dollar and two drops of catalyst is a good rule of thumb for use.

2. Mix silastic and catalyst in the glovebox for use as needed. This will allow more working time than if the mixture is made outside the box.

3. Mix catalyst well with a spatula. Areas of silastic which do not receive any catalyst will not cure properly, will not replicate, and will leave a residue on the part.

4. Avoid entrapping air during mixing. This produces small bubbles which leavc holes in the replira.

5. Use a spatula to spread a $1 / 8$ in. layer of silastic on the part; allow it to smooth out while still fluid. A smooth top surface permits the replica to be conveniently placed on a glass slide for easy measurement under the microscope. Use scissors to trim the replica to a convenient size to fit a glass slide.

6. When using 0.5 percent catalyst, allow to cure five to six rninutes.

7. Several basic features should be included in the microscope used to examine the replicas. These are: a graduated fine focus mechanism; binocular eye pieces; vertical illumination; and convenient stage traversing controls. Magnification in the range of 150-200x is recommended for examination of the replicas. 
TABLE I

OPTICAL DEPTH MEASURIMENTS OF REPLICATED DEFECTS

\begin{tabular}{|c|c|c|c|c|c|c|c|c|c|c|c|c|c|}
\hline \multicolumn{2}{|c|}{ Standard } & \multicolumn{2}{|c|}{$\begin{array}{c}0.005 " \text { Fax No. } 1 \\
\text { as stripped } \\
\end{array}$} & \multicolumn{2}{|c|}{$\begin{array}{c}0.005^{\prime \prime} \text { Fax No. } 1 \\
\text { Ag-coated } \\
\end{array}$} & \multicolumn{2}{|c|}{$\begin{array}{c}0.005^{\prime \prime} \text { Fax No. } 2 \\
\text { as stripped } \\
\end{array}$} & \multicolumn{2}{|c|}{$\begin{array}{c}0.005^{\prime \prime} \text { Fax* No. } 2 \\
\text { Ag-coated } \\
\end{array}$} & \multicolumn{2}{|c|}{$\begin{array}{c}\text { Dow Corning } \\
\text { Silastic RTV } 521 \\
\end{array}$} & \multicolumn{2}{|c|}{$\begin{array}{c}\text { General Electric } \\
\text { RTV } 20 \\
\end{array}$} \\
\hline lo. & $\begin{array}{l}\text { Depth }{ }^{1} \\
\text { (in.) }\end{array}$ & $\begin{array}{l}\text { Depth }{ }^{2} \\
\text { (in.) }\end{array}$ & $\begin{array}{l}\text { Variation } \\
\text { from Std. }\end{array}$ & $\begin{array}{c}\text { Depth } 2 \\
\text { (in.) }\end{array}$ & $\begin{array}{l}\text { Variation } \\
\text { from Std. }\end{array}$ & $\begin{array}{l}\text { Depth }{ }^{2} \\
\text { (in.) }\end{array}$ & $\begin{array}{l}\text { Variation } \\
\text { from Std. }\end{array}$ & $\begin{array}{l}\text { Depth }^{2} \\
\text { (in.) }\end{array}$ & & $\begin{array}{l}\text { Depth }^{2} \\
\text { (in.) }\end{array}$ & $\begin{array}{l}\text { Variation } \\
\text { from Std. }\end{array}$ & $\begin{array}{l}\text { Depth }^{2} \\
\text { (in.) }\end{array}$ & $\begin{array}{c}\text { ation } \\
\text { Std. }\end{array}$ \\
\hline & 005 & & $-(1.00124$ & 440 & & & & & & & +0.00004 & & \\
\hline & 0 & & 0 & Not r & & 0484 & -0.0 & & & & 0 & & \\
\hline 3 & 0.00392 & 00412 & $+(4.00020$ & 00432 & +0.00040 & .00376 & -0.00016 & & & & & & \\
\hline & 0.00396 & 00376 & $-(1.00020$ & & & .00408 & +0.00 & & & & & & \\
\hline 5. & .00464 & 00412 & -0.00 & & & .00408 & & & & 0.00456 & -0.00008 & & \\
\hline 6. & 0.00380 & 0.00364 & $-c .00016$ & 0.00368 & $-0.000] 2$ & 0.00364 & -0.00016 & 0.00324 & -0.00056 & 0.00360 & -0.00020 & 0.00392 & +0.00012 \\
\hline
\end{tabular}

* Cellulose acetate film.

1. Determined optically on test sample - average of 10 readings.

2. Average of six readings. 
THE DOW CHEMICAL COMPANY

ROCKY FLATS DIVISION

P. O. BOX 938

GOLDEN, COLORADO 80402 